\title{
What Are the Factors Affecting the Use of English Language in English-only Classrooms: Student's Perspectives in Pakistan
}

\author{
Sadia Asif ${ }^{1}$, Rahat Bashir $^{1} \&$ Shabana Zafar ${ }^{1}$ \\ ${ }^{1}$ Institute of Communication and Cultural Studies, University of Management and Technology, Lahore, Pakistan \\ Correspondence: Sadia Asif, Institute of Communication and Cultural Studies, University of Management and \\ Technology, Lahore, Pakistan. E-mail: sadiaasif2002@gmail.com
}

Received: February 21, 2018 Accepted: May 10,2018 Online Published: May 12, 2018

doi: 10.5539/elt.v11n6p67 URL: http://doi.org/10.5539/elt.v11n6p67

\begin{abstract}
English as a medium of instruction and communication is becoming a central pedagogy in various countries in the world. In Pakistan, most of the advanced academic institutions use English as their medium of instruction, however students and teachers have been observed communicating in their first languages, especially Urdu, in the classrooms. This study was conducted at the Institute of Communication and Cultural Studies, University of Management and Technology, to examine the factors that limit students and teachers from communicating in English. Qualitative research methods were employed to find the factors affecting the use of English in English-only classrooms. A total of 130 participants were included in this study. Among them, 68 participants were engaged in student questionnaires. The participants were students of four native languages (Urdu, Punjabi, Siraiki and Pushto) with different level of English language proficiency. Required literature search was performed using key databases and journals, related to applied linguistics, English language and education. Our results demonstrated that most of the students like to communicate in English and be a part of the English-only environment, however they acknowledged some key factors that prevented them from speaking English in the classrooms. Fundamental factors included linguistics, individual, social, psychological and institutional which were largely based upon their beliefs, assumptions, needs and desires. This study may provide insights to the policymakers to work on issues related to communications and medium of instructions in Pakistan. It may also help teachers and educators to understand the underlying factors that compel students to speak their first languages instead of English.
\end{abstract}

Keywords: medium of instruction, Pakistan; English language, student's perception, classroom

\section{Introduction}

With the increasing internationalization of higher education, English Medium Instruction (EMI), has become a key module in content and language integrated learning (CLIL), specially in those countries who want to be part of the global economy. In the $20^{\text {th }}$ century, English language made a pervasive progress to become a language of international diplomacy, commerce, education, science and technology. This paradigm shift is on the rise, with significant impact on policy making regarding medium of instructions, however English as a Second Language (ESL) in the classrooms has long been a subject of debate, especially in European and Asian countries (Coyle, 2010; Coleman, 2006; Chan \& Tan, 2006). In many instances, student find EMI helpful in improving their English proficiency, however they find it hard to understand English lectures in the classrooms (Chen \& Tsai, 2012; Joe \& Lee 2013).

The use of L1 in the English classroom has been and will remain an issue that everyone has an opinion about, either against or for it. Various studies have shown that students first language play an important part in the learning of target language (Lightbown \& Spada, 2013; Rivers, 2011), however, there is another school of thought that believes that massive exposure to target language is required in order to maximize the learning process for the learner (Rawan, 2016).

In Pakistan, students and teachers in the English language classroom tend to hold on to their first language and most of the time they have been observed speaking Urdu even in their English language classroom. Most of the studies on the use of L1 in English classrooms usually ignore the viewpoint of the students or highlight only the teachers' opinions. Additionally, these studies have been mostly conducted in EFL settings, rather than ESL. In this study, we explore opinions, attitude and reasons of learners regarding their use of native language when they 
are in English language classroom, a place where English language is thought to be spoken. This study tries to go deeper in this area and to discover the reasons behind using native language in ESL settings.

\subsection{Research Aim}

This is a pilot study and the aim of this study is to give deeper insight why Pakistani students use their mother tongue in English only classrooms. We will investigate and look at nonnative English student's perspective. This study will try to explore student's thoughts and potential reasons for speaking mother tongue instead English, in English language classrooms. Results from this study will help students to look themselves and find better ideas and explanations for their attitude towards English language learning. By realizing, they may come up with better solution to enhance their language skills. This study may also be helpful for the teachers and will enhance their understanding for the problems, faced by their students. It may also provide information for the teachers and educationists in Pakistan on how to generate better materials and methods for the effective use of English in English only classrooms.

\subsection{Theoretical Framework}

This study will be comprised of a combination of a social constructionist and a constructivist theoretical framework. We will investigate the constructivist aspect to identify social realities that put hindrances to the learning process. If students are supposed to speak English, then what are the factors that force student to switch to local languages such as Urdu. We will discuss and extract individual perspectives of students for having pro/anti views about English language in the classroom. In social constructionism, we will be discussing the likelihood of role played by the culture and social realities in the process of learning. This will also shape up the factors that influence the student in adopting English language as a medium of instructions and the factors that deviate them from using English language in the classrooms (Fenton-Smith, 2015). Subjects such as students and teachers bring activities that function as object (purpose of the activity). Then we have policy makers who govern the activity designed for students and teachers (Wen, 2014; Danielewicz, 2001). The above mentioned theoretical elements will be combined in the theoretical framework of this project. Moreover, this theoretical framework will also portray the debate around the use of either L1 or L2 with the support of research findings. Adopting L1, L2 or both have their own dimensions, social parameters and advantages and disadvantages EFL classrooms. In the light of our pilot results, we will provide reasons why is it so challenging to adopt only L1 or only L2 in Pakistan. We will also provide reasons how selective use of L1 can facilitate the learning of L2 in the English only classroom.

The role of L1 has resulted in an increasing repertoire of relevant research studies supporting the benefits of selective use of L1 from different sociolinguistic contexts that not only provide insights into the favorable attitudes from both teachers and students toward L1 use but also support the premise that L1 can actually facilitate L2 learning. Drosatou (2009) conducted a study involving six Greek English language teachers as well as 30 students in her study. The study's aim was to analyze to what extent Greek language was used in the L2 classroom. The results showed that teachers were likely to use L1 in the classroom and that students were mostly in favor of using both languages in class. In a study, McMillan and Rivers (2011) tried to investigate the perspectives of native English teachers in Japan towards the use of L1 (Japanese) in English only policy setting. Their study reveal that native English teachers viewed the use of L1 positively. The authors argued that selective use of L1 can play a communicative, cognitive and social role in the learning of L2.

In the interactionist framework, it is important to be exposed to maximum amount of L2 and that is the key to learn language. L2 is the key, as languages are best learned when students use them to negotiate meaning and make sense of what they hear (Ellis, 2008). Krashen (1982), adhering to input hypothesis based on negotiating meaning and emphasizing L2 input, praises interactionism. Anton and DiCamilla (1998) mention that those who favor a sociocultural viewpoint are very much at odds with those who work within the interactionist framework, implying that the views of the two perspectives taken in their pure forms cannot be reconciled. But the difficulty when viewing these two frameworks as oppositional, of course, is that one theory of second language acquisition cannot possibly give a complete picture of the L2 acquisition process. (How) Can it be that only the sociocultural framework or only the interactionist framework is true? Clearly, in a foreign language classroom, students have needs that stem from both of these frameworks. As Grammar Translation and Communicative Language Teaching are polar opposites of each other both in theory and in their dictums regarding L1 use, and the sociocultural framework contradicts the isolationist framework, a more balanced approach is starting to emerge in the literature. It stipulates that the L1 does have a place in the classroom, but that it should only be used minimally, so that learners receive as much L2 input as possible. 


\section{Methodology}

The research questions to be explored in this study are exploratory in nature, as this study tries to find factors affecting student's language choices inside the classroom. Therefore, qualitative framework has been used in the study, as Evans (2001) rightly points out that numbers and statistical analysis cannot allow us to see what is in the students' minds; it also does not let us hear their voices. Therefore, qualitative methods seemed to best fit the purposes of this study.

\subsection{Participants}

The participants of the study were 68 EFL learners including males and females between the ages of 19-22; these participants belong to three different section of the same course. The participants had already passed two courses of English language. All the participants were enrolled in the third semester of English language offered by Institute of Communication and Cultural Studies (ICCS) at University of Management and Technology (UMT). All of them had passed basic and intermediate level of English courses known as "English Grammar and Composition" and "English Comprehension and Composition". All the participants were enrolled in "Technical Writing and Research Skills". The participants of study were doing Bachelor's in Engineering. Most of the participants had started learning English at the ages of 5-12. The native languages of these learners were either Punjabi, Siraiki, Pushto or Urdu (Pakistan's local languages).

\subsection{Context}

The study was conducted at the Institute of Communication and Cultural Studies (ICCS) at University of Management and Technology (UMT). The ICCS offers three level the basic knowledge of English program where students gain basic knowledge of English Grammar and Composition. This level is called English 1 and then Intermediate level where students acquire the knowledge of Comprehension and Communication skills. This is known as English 2. The students included in this study belong to high Intermediate level. They learn Technical Writing and Communication skills and this level course is called English 3 at ICCS. Most of the ICCS students come from different parts of Pakistan.

\subsection{Data Collection}

The data collections for this study were through triangulation i.e. by mean of three distinct data gathering tool. The study is exploratory by nature therefore it was conducted within a qualitative framework to collect data that see through students attitude and opinion. The methods and instruments used in the study are given below.

\section{1). Questionnaire}

Questionnaire was developed in consultation with two faculty members from Applied Linguistic and some amendments in the questionnaire were made after their suggestions. The questions in this study were not presented with an approach that would make participants respond in a particular order. Each question was established to be answered only, depending on the content of the question.

\section{2). Semi-structured Interviews from Individual Students}

The second phase of this study was follow up interviews. There were total 10 questions in the interview. Participants had to answer how they have studied English and about their first language. We carried out semi-structured interviews with the students on 5th week of the semester. The interview questions helped to deeper understand the attitude and opinions of the learners. Total 20 students were randomly picked for the interviews.

\section{3). Focus-Group Interviews}

Interviews of focus groups were conducted on the 7th and 8th week of the semester. The focus group consisted of two groups: those who were in the favor of using English Only policy in the classroom (English Focus Group) and those who were against using it (Urdu Focus Group).

\section{Results and Discussion}

In this study, we enrolled a total of 70 participants, among them 68 participants responded to our questionnaires and interviews. Participants were speakers of different local languages including Urdu (62\%), followed by Panjabi (24\%), Siraiki (9\%) and Pashto (6\%) as shown in Figure 1. Similarly, Institute of Communication and Cultural Studies (ICCS) at the University of Management and Technology (UMT) offers three levels, the basic knowledge of English program where students gain basic knowledge of English Grammar and Composition. This level is called English 1 and then Intermediate level where students acquire the knowledge of Comprehension and Communication skills. This is known as English 2. The students included in this study 
belong to high Intermediate level. They learn Technical Writing and Communication skills and this level course is called English 3 at ICCS. Most of the ICCS students come from different parts of Pakistan. As shown in Figure 2, majority of the participants were at advanced level (82\%) followed by intermediate (12\%) and basic level (6\%). The English proficiency of majority of the students was at level $5(31 \%)$ followed by level 6 and 7 (both 22\%). There was only one participant who rated his English proficiency at level 10 (Figure 3).
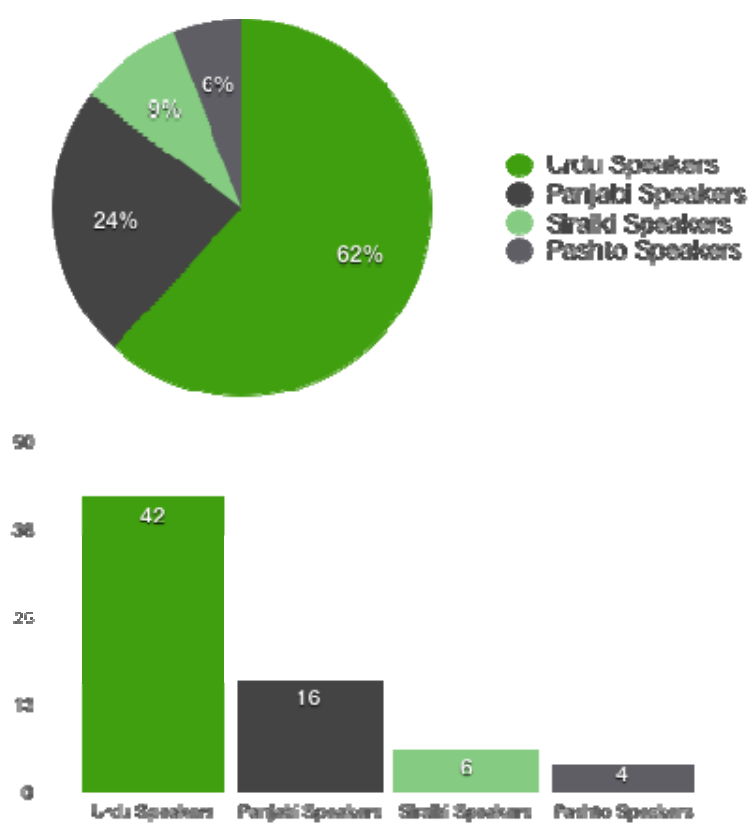

Figure 1. Shows the number and percentage of participants speaking different local languages including Urdu (62\%), Panjabi (24\%), Siraiki (9\%) and Pashto (6\%). Participants were asked "what is your first language?"

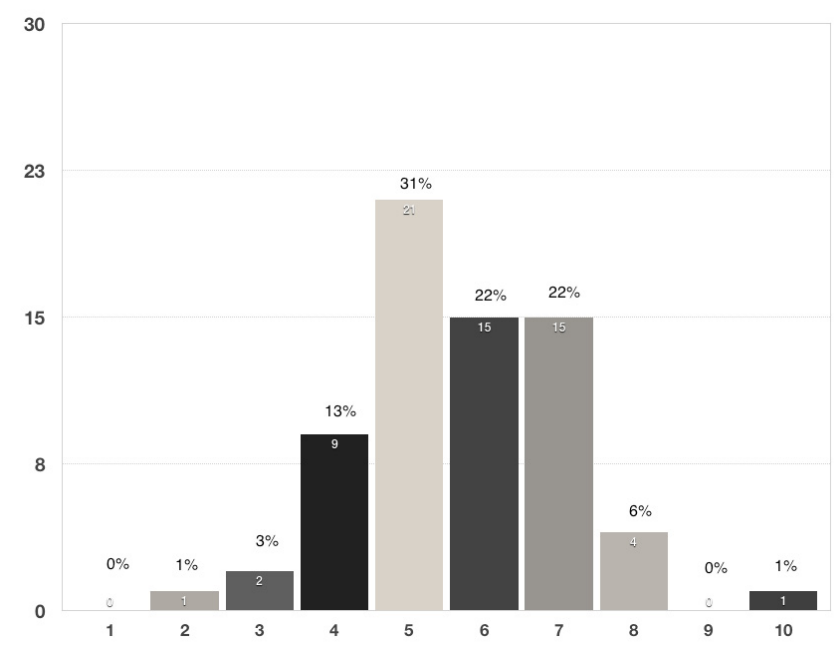

Figure 3. This shows rating of English proficiency of all participants. They were asked "on a scale from $0-10$, how do you rate your English language proficiency?" At " 5 " they rated themselves the most (31\%)
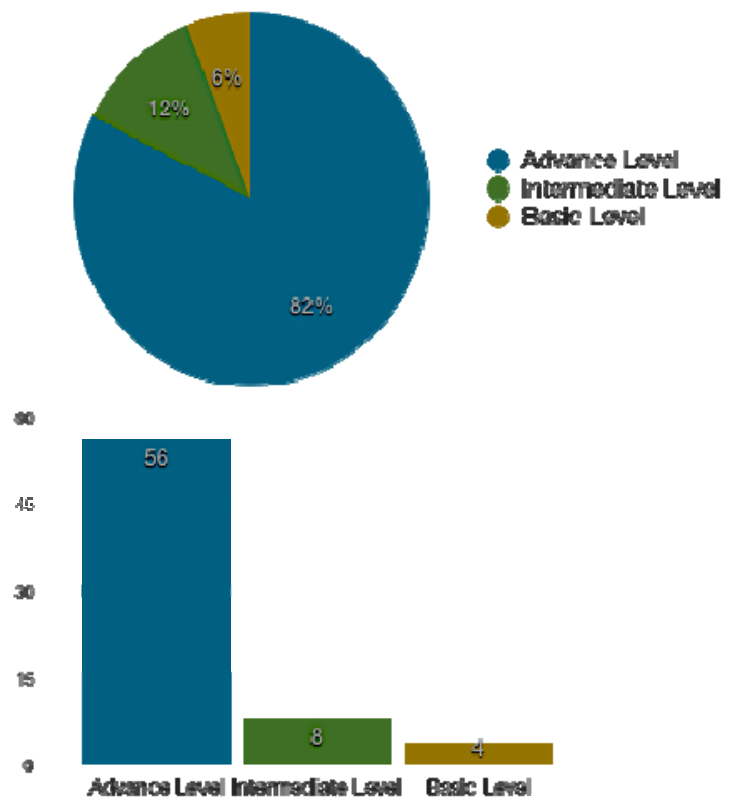

Figure 2. The participants were asked "at what level are you studying English language course at ICCS,

UMT?". This figure shows the number and percentage of participants at advance level, intermediate level and basic level

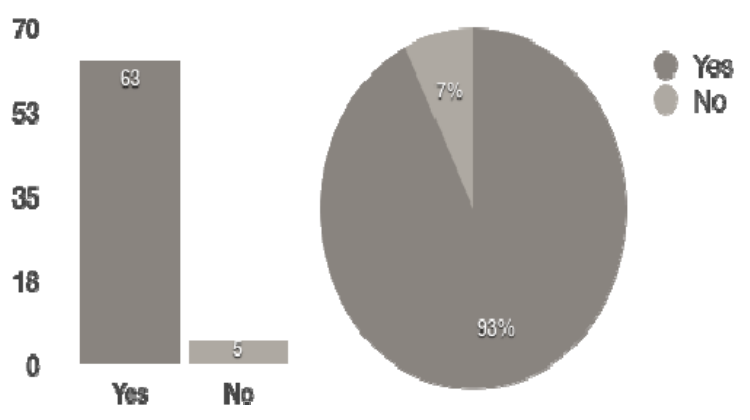

Figure 4. When Participants were asked "do you like English-only Policy in Language classroom?", majority of them (93\%) said "Yes" 
The use of the first language Studies discussing the use of the mother tongue in general, i.e., the first language, usually study the use of L1 without focusing on any specific language. Vivian Cook's (2001) argues against the notion that the second language should be learned without interference from any other language, similar to the way a person learns the first language. He points out that the learner is now more mature and can incorporate the use of L1 while learning a second language. The learners instinctively connect the syntax, phonology and vocabulary of their first and second languages according to their own minds, and should not be discouraged. Cook further goes on to show how teachers can use the first language into the learning of a second language. New vocabulary and grammar rules could be better understood using L1, but the use of the first language should not be dominant. A study was conducted by Bouangeune (2009) in Laos on using the first language to improve English learning. Two study groups were used, an experimental and a control group, with only the experimental group using the first language. The study showed an improved in learning English in the experimental group, which was attributed to the use of $\mathrm{L} 1$.

Both inclusion and exclusion of L1 from EFL classes has been a great topic of debate for the researchers (Kavaliauskienë \& Kaminskienë, 2007; Storch \& Wigglesworth, 2003; Wells, 1999; Alshammari, 2011; Jarvis, 2000; Kafes, 2011; Auerbach, 1993; Khresheh, 2012; Levine, 2003; Spada \& Lightbown, 1999; Rayati, Yaqubi, \& Harsejsani, 2012;). Majority of these researchers from different countries have debated that using the students' L1, be it teacher or students, can assist language learning (Mart, 2013; Kafes, 2011; Jafari \& Shokrpour, 2013) although a minor number of studies propose that language learners may also be unwilling to use their L1 (Nazary, 2008).

Over a couple of decades ago, Auerbach (1993), took a different approach (contrary to common assumptions) and cast doubt on the prevalent English-only policy. Auerbach (1993) clearly stated, "we are in need to identify that respect for learners and languages has powerful social implications". Other studies have also examined the L1 impact on L2 learners (Jarvis, 2000; Spada \& Lightbown, 1999), the effect of earlier introduction to theories and research on student teachers code-switching in secondary schools (Macaro, 2001), the relationship between target language and first language use and anxiety (Levine, 2003), and the use of L1 in communicative approach settings (Storch \& Wigglesworth, 2003).

Our results demonstrated a strong leaning towards English only Policy in classroom. Among 68, 63 (93\%) participants voted for English only policy while 5 (7\%) participants voted against it (Figure 4, Figure 5). The focus group interviews were conducted on the 7 th and 8 th week of the semester. The focus group consisted of two groups: those who were in the favor of using English only policy in the classroom and those who were against using it. We were interested why majority of the participants want English only policy in the classrooms. We conducted focus group interviews and according to our English Focus Group results, multiple reasons were unveiled by the participants (Table 1, Table 2). Majority of them were of the opinion "We should have English only classrooms because we want to learn fluent English. It is international language. We want to learn fluency in English that will be helpful in other countries". 
Table 1. English focus group: Why do you think it is important that we should have English only policy in our English Language classrooms?

\begin{tabular}{|c|c|}
\hline Students & Students Reply/Comment \\
\hline 1 & $\begin{array}{l}\text { We should have English only classrooms because we want to learn fluent English. It is international } \\
\text { language. We want to learn fluency in English }\end{array}$ \\
\hline 2 & It is helpful in other countries therefore we want English \\
\hline 3 & To generate good speakers, we should have English only classrooms \\
\hline 4 & Speaking power is poor. To enhance English, power this is necessary \\
\hline 5 & $\begin{array}{l}\text { Spoken was very weak. I can see difference in my ability in this semester. I can see betterment in this } \\
\text { semester }\end{array}$ \\
\hline 6 & It enhances our listening, learning and spoken. \\
\hline 7 & We communicate in English. It is a good policy for English class that enhance our learning ability. \\
\hline 8 & $\begin{array}{l}\text { We could get competition in the market when we get in our practical life. Most of the work is in } \\
\text { English so we have challenges so we should good power. }\end{array}$ \\
\hline 9 & All of us feel comfortable with English only policy in English classrooms. \\
\hline
\end{tabular}

Table 2. English focus group: Why do you think English language policy is a good policy?

\begin{tabular}{|c|c|}
\hline Students & Students Reply/Comment \\
\hline 1 & $\begin{array}{l}\text { It motivates us to speak English. Only high society people are motivated to talk in English but } \\
\text { English only policy motivates us to speak in English }\end{array}$ \\
\hline 2 & $\begin{array}{l}\text { We should have an environment in our university and in our classrooms, we should have on place } \\
\text { where we should speak English too }\end{array}$ \\
\hline 3 & $\begin{array}{l}\text { We should have environment in our university and in our classroom, we should have one place } \\
\text { where we should talk in English with our fellows. we talk normal things like stories in English, we } \\
\text { used to talk daily outside the class also }\end{array}$ \\
\hline 4 & $\begin{array}{l}\text { We cannot totally! My family members think that I am showing off and these kinds of funny } \\
\text { comments are passed on me and on the speakers. }\end{array}$ \\
\hline 5 & $\begin{array}{l}\text { Ma'am English is an international language and we cannot deny that fact. We have to talk in English } \\
\text { if we want to succeed and reach at a certain level-to reach at our full potential we should know how } \\
\text { to speak English and for that English only policy has really improved our confidence. It has given us } \\
\text { the confidence to speak English more frequently. That's how English in the classroom has helped us } \\
\text { a lot. }\end{array}$ \\
\hline 6 & Ma'am it's a global language and that's why we have to learn it. \\
\hline 7 & To improve one's confidence we have to talk in front of somebody. \\
\hline 8 & $\begin{array}{l}\text { We should not only learn English but we should also learn Punjabi, Siraiki, Pushto, Sindhi and other } \\
\text { languages that are being used in our country. }\end{array}$ \\
\hline 9 & $\begin{array}{l}\text { In speaking English, we have the rules of the grammar, I think we should must neglect the rules of } \\
\text { the grammar while speaking any kind of language }\end{array}$ \\
\hline
\end{tabular}


Table 3. English focus group: Do you feel any fear while using English language? Any social or psychological fear?

\begin{tabular}{ll}
\hline Students & Students Reply/Comment \\
\hline 1 & When we go to villages our surrounding is all Punjabi so we cannot use English there \\
2 & $\begin{array}{l}\text { When we have to express our feelings, we feel that Urdu is a better language and we can convey our } \\
\text { message properly }\end{array}$ \\
3 & $\begin{array}{l}\text { Our confidence level is not high. When talking in English we get stuck so we switch to Urdu } \\
4\end{array}$ \\
& $\begin{array}{l}\text { When we are doing questions in math's or any subject questions all questions are in English and we } \\
\text { have to convert those questions to Urdu language in order to understand those questions }\end{array}$ \\
\hline
\end{tabular}
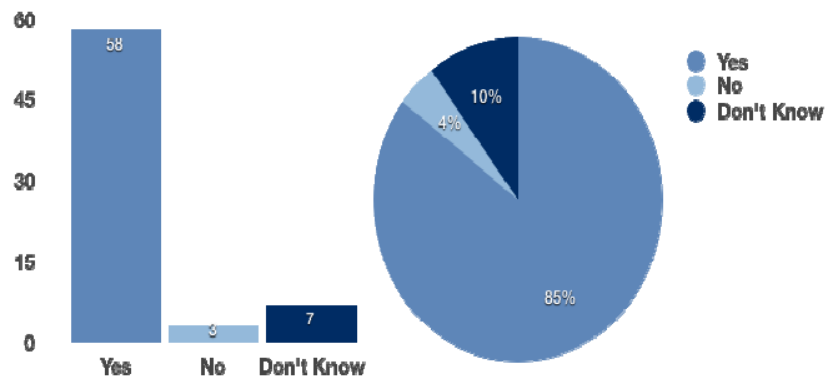

Figure 5. Shows the participants response in "Yes", "No" or "Don't know" when they were asked "do you think your English is improving by English only policy in the classroom?"
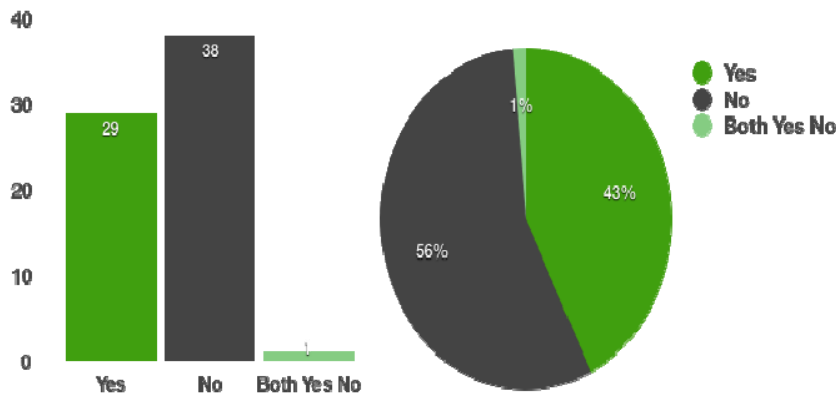

Figure 7. Participants were asked "Does English only policy makes you nervous in the class?". This figure shows their response in "Yes", "No" or "Both yes and no"
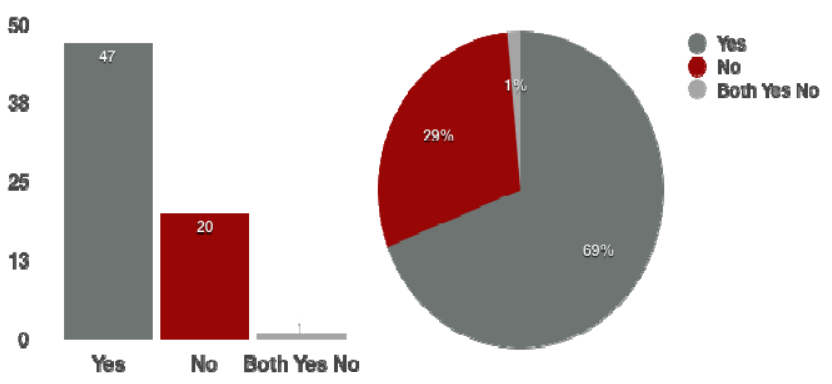

Figure 6. Figure 5 shows the number and percentage of participants who responded to a question "are you motivated to talk in English outside your English language classroom?"

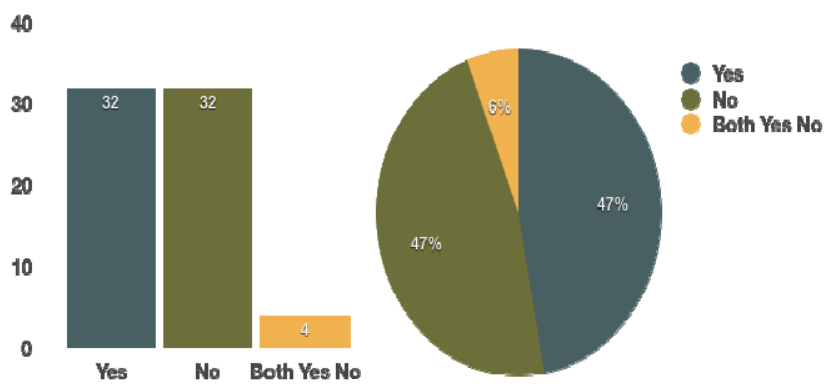

Figure 8. Shows the response of students in "Yes", "No" or "Both yes and no" when they were asked "Do you think teacher should speak only English in the classroom?"

Oral communication is affected by various factors including social, institutional, psychological, and linguistic factors. In our study, when the participants were asked "are you motivated to talk in English outside your English language classroom?", majority of them replied positively (69\%) as shown in Figure 6. We wondered, if they are motivated, then what are the factors that hindered them to speak English outside the classrooms. Participants articulated several factors (Table 3) including psychological, social and cultural as shown in Figure 7. Parallel to our study, Park's (1998) carried out his study beyond the classroom. He examined various factors affecting the oral communication. Under the social factors he describes peer pressure, social norms and values, and cultural communication patterns. Institutional factors included teacher characteristics, classroom setting, topics, unequal turn distribution, and class size. The psychological factors included lack of confidence in using English with other Koreans and fear of making mistakes due to fear of being judged. Finally, the linguistic factors were translating habits, lack of listening comprehension, and limited linguistic resources. An overview of these three studies (Hwang, 1993; Park, 1998; Tomizawa, 1990), shows that the same categories of factors affected the communication patterns of students in Pakistan.

In a study, Kang's (2006) concluded that two main sociocultural factors prevented the participant from using 
English: lack of contact with native speakers and the feeling of insecurity about speaking English in the presence of other Koreans. Kang argued that individual factors of English learners could help them cope with the challenges brought by socio-contextual and cultural aspects that limit usage of English. In summary, the works of Tomizawa (1990), Hwang (1993), Park (1998), and Kang (2006) have extensively described a number of factors pertaining to the language choices made by Asian student in their communication in class and outside of the classroom. In addition, two of these studies (Kang, 2006; Park, 1998) have demonstrated that the context in which students learn the language plays a significant role and in many ways, determines learner communication styles. Our study shows parallel factors that limit Pakistani students to communicate in English.

The role of teacher in the classroom has been investigated by many researchers. In our study as shown in Figure 8, participants responded equally to a question "Do you think teacher should speak only English in the classroom?" Interestingly 47\% students replied "Yes" and same answered in No. Just $6 \%$ were on the opinion of both "Yes and No" owing to the contents and circumstances of lectures in the classrooms (Table 4). Similarly, Schweers (1999) also investigated at Puerto Rican university with 19 teachers and their students in an EFL setting. The purpose of the study was to examine the students and teachers attitudes toward using Spanish language in the L2 classroom. The results exhibited positive outcomes towards English learning while using Spanish in the classrooms that consequently encouraged students to learn more English. Another similar study was conducted in China by Tang (2002) with 20 teachers and 100 students. The objective was to explore the students and teacher's attitudes toward using Chinese in the L2 classroom. Their results revealed that limited and judicious use of the mother tongue in the classroom did not reduce students' exposure to English but rather, assisted in the process of teaching and learning. Miles (2004) used three low- level first-year university classes of Japanese students to uncover suggestion of the theory that L1 use can assist L2 learning. The outcomes demonstrated that L1 use in the English classroom did not deter L2 learning but rather assisted it.

Table 4. Urdu focus group: Do you feel comfortable in English only classroom?

\begin{tabular}{ll}
\hline Students & Students Reply/Comment \\
\hline 1 & $\begin{array}{l}\text { when we are not using tough vocabulary, it's okay but when we use tough vocabulary it's difficult to } \\
\text { understand in English }\end{array}$ \\
2 & $\begin{array}{l}\text { we can convey our message more clearly and efficiently in our native language. We can convey } \\
\text { powerful. }\end{array}$ \\
4 & we are shy and we are not confident \\
\hline
\end{tabular}

The debate about the use of L1 in the EFL classroom has been a controversial issue and the subject of ample research and investigation. There are numerous authors who support monolingualism in EFL who advocate that English should be used exclusively inside the classroom as the main teaching and learning medium with no use of the L1 (Polio \& Duff, 1994). Such assumptions clearly claim that L2 is advisable, appropriate and according to the norm, while L1 is a taboo and detrimental (Prodromou as cited in Butzkamm, 2003, p. 29). This notion is implicitly or explicitly, supports the supposition that English is the only suitable way to communicate in the EFL classroom (Auerbach, 1993). However, various authors have rejected such assumptions (Atkinson, 1987; Butzkamm, 2003; Cook, 2001). They have tried to defy such assumptions in which L2 has been thought to be the only communication language (Auerbach, 1993). They have been advocating the role that L1 could play specially in countries where English is not the mother tongue of the students. In our Urdu focus study group (Table 5 and Table 6), students gave a myriad of reasons why should Urdu be adopted in the classroom. They believed, classrooms in Pakistani institute have students coming from remote areas, and they find it hard to communicate in English. Some participants argued that when they go to Japan and China, they have to learn their respective languages, so why shouldn't they be sticking to Urdu, instead English. 
Table 5. Urdu focus group: What is your take? Why do you think we should have Urdu in our classrooms?

\begin{tabular}{ll}
\hline Students & Students Reply/Comment \\
\hline 1 & As English is neither our national language nor our mother language so it is not convenient to learn in \\
& English. It is better to talk in Urdu than in English to understand things in a better way. \\
2 & $\begin{array}{l}\text { English is not a compulsory language to learn. it is necessary to learn to communicate with the world. } \\
\text { We have many people who cannot understand even Urdu in our society. }\end{array}$ \\
3 & It is our mother tongue, only few people understand English so we should use English \\
& $\begin{array}{l}\text { It is our national language. Like any other successful country like Japan and China, they are using } \\
\text { their own languages. They even communicate with the world in their language so it is your turn to } \\
\text { make them understand your language instead of learning their language. }\end{array}$ \\
\end{tabular}

Table 6. Urdu focus group: Why do you think students use Urdu in English-only classrooms?

\begin{tabular}{ll}
\hline Students & Students Reply/Comment \\
\hline 1 & I think many students in our university are from rural areas - they do not have enough exposure to \\
& English Language. So, we should not make English as a medium of instruction for them. \\
& $\begin{array}{l}\text { Many students cannot understand a lot of things in English so it is better for us to say things in } \\
\text { English }\end{array}$ \\
3 & $\begin{array}{l}\text { (in Urdu) When we go to china, we learn Chinese and when we go to Germany, we learn German. } \\
\text { Why we have to learn their language? Why can't they learn our language? }\end{array}$ \\
5 & Lack of confidence \\
& $\begin{array}{l}\text { Our surrounding and environment - No one talks in English around us. If we talk to our friend or } \\
\text { relatives in English, they make fun of us. }\end{array}$ \\
\hline
\end{tabular}

Polio and Duff (1994) are of the opinion that if L1 is used in the classroom for the facilitation of interaction, then the students might not look at L2 as the only appropriate way to communicate ideas (Polio \& Duff, 1994.) Another argument against the use of the L1 arises from the fact that most of the time, the L1 is used inconsistently or in unprincipled ways. If the speaker can't speak L1 with good reasons, then the use of L1 cannot be justifies as pedagogy. Macaro (2001) investigated to know how teachers choose to use the students' L1 in the classroom. Another critique of the inconsistent and unprincipled use of L1 comes from a study conducted by Turnbull's (1999). All these studies are in accordance of our results and observations.

\section{Conclusion}

Focusing on the use of L1 and L2 in English only classroom, this research presents detailed analysis of Pakistani student's perceptions on the use of L1. We found an array of perceptions behind the use of local languages in the English only classrooms. We summarize that the best model for Pakistani student is to make selective use of L1 in the L2 classrooms. According to our results, most of the students like to communicate in English and be a part of the English-only environment, however they acknowledged some key factors that prevented them from speaking English in the classrooms. Fundamental factors they spoke about were personal, linguistic and social. There were also various psychological and institutional hindrances and all these factors were largely based upon their beliefs, assumptions, needs and desires. They mentioned several social barriers including shyness while speaking in English language. This study may provide insights to the policymakers to work on issues related to communications and medium of instructions in Pakistan. It may also help teachers and educators to understand the underlying factors that compel students to speak their first languages instead of English. These teachers may focus on basic communication skills in English to their students who would be learning other subjects in their own languages in Pakistan. Our study also provides insights for the reformers and educators about how to give richer understanding while diluting the barriers among the students, with culturally and contextually more sustainable environment in the classroom.

\section{Competing Interest Declaration}

It is declared that there is no competing interest involved with this study 


\section{References}

Al Hinai. (2006). The use of the L1 in the elementary English language classroom. In S. Borg (Ed.). Classroom research in English language teaching in Oman. Muscat: Ministry of Education, Sultanate of Oman.

Alshammari, M. M. (2011). The Use of the Mother Tongue in Saudi EFL Classrooms. Journal of International Education Research, 7(4), 95-102. https://doi.org/10.19030/jier.v7i4.6055

Anton, M., \& DiCamilla, F. (1998). Socio-cognitive functions of L1 collaborative interaction in Auerbach, E. R. (1993). Reexamining English only in the ESL classroom. TESOL Quarterly, 27, 9-32.

Atkinson, D. (1987). The mother tongue in the classroom: a neglected resource? English Language Teaching Journal, 41(4), 241-247. https://doi.org/10.1093/elt/41.4.241

Auerbach, E. (1993). Reexamining English only in the ESL classroom. TESOL Quarterly, 27, 9-32. https://doi.org/10.2307/3586949

Barker, D. (2003). Why English teachers in Japan need to learn Japanese. The Language Teacher, 27(2).

Bouangeune, S. (2009). Using L1 in teaching vocabulary to low English proficiency level students: A case study at the University of Laos. English Language Teaching Journal, 2(3), 186-193.

Brown, H. (2007). Principles of Language Learning and Teaching (5th ed.). White Plains, NY: Pearson Longman.

Burden, P. (2001). When do native English speakers and Japanese college students disagree about the use of Japanese in the English conversation classroom? The Language Teacher, 25(4).

Butzkamm, W. (2003). We only learn language once. The role of the mother tongue in FL classrooms: death of a dogma. Language Learning Journal, 28, 29-39. https://doi.org/10.1080/09571730385200181

Carless, D. (2008). Student Use of the Mother Tongue in the Task-Based Classroom. ELT Journal 62(4), 331-338. https://doi.org/10.1093/elt/ccm090

Chan, S. H., \& Tan, H. (2006). English for Mathematics and Science: Current Malaysian Languagein-Education Policies and Practices. Language and Education, 20(4), 306-321. https://doi.org/10.2167/le631.0

Chen, S., \& Tsai, Y. (2012). Research on English teaching and learning: Taiwan (2004-2009). Language Teaching, 45(2), 180-201. https://doi.org/10.1017/S0261444811000577

Coleman, J. A. (2006, January). English medium teaching in European Higher Education. Language Teaching, 1(1), 1-14. https://doi.org/10.1017/S026144480600320X

Cook, V. (2001). Using the First Language in the Classroom. The Canadian Modern Language Review, 57(3), 402-23. https://doi.org/10.3138/cmlr.57.3.402

Coyle, D., Hood, P., \& Marsh, D. (2010). CLIL: Content and Language Integrated Learning. Cambridge: Cambridge University Press.

Crotty, M. (1998). The foundations of social research. London: Sage Publications.

Daily-O'Cain, J., \& Liebscher, G. (2009). Teacher and student use of the first language in foreign language classroom interaction: functions and applications. In M. Turnbull, \& J. Dailey-O'Cain (Eds.), First language use in second and foreign language learning (pp. 131-144). Bristol, UK: Multilingual Matters.

Danielewicz, J. (2001). Teaching selves: Identity, pedagogy and teacher education. Albany: SUNY.

Davila, S. L. (2005). Tips and techniques for the English only classroom. Retrieved from http://www.saradavila.com/english/english.doc

Drosatou, V. (2009). The use of the mother tongue in English language classes for young learners in Greece. Unpublished Ph.D. thesis, University of Essex, the UK.

Duff, P., \& Polio, C. (1990). How much foreign language is there in the foreign language classroom? Modern Language Journal, 74, 154-166. https://doi.org/10.1111/j.1540-4781.1990.tb02561.x

Edstrom, A. (2006). L1 use in the L2 classroom: One teacher's self-evaluation. The Canadian Modern Language Review, 63, 275-292. https://doi.org/10.3138/cmlr.63.2.275

Ellis, R. (2008). The study of second language acquisition. Oxford: Oxford University Press.

Gearon, M. (1998). Codeswitching between English and French among teachers of French as a foreign language 
in Australia. Etudes de Linguistique Appliquée, 108, 467- 474.

Hedge, T., \& Whitney, N. (eds.). (1996). Power, Pedagogy \& Practice. Oxford. Oxford University Press.

Hellermann, J., \& Pakarek Doehler S. (2010). On the contingent nature of language-learning tasks. Classroom Discourse, 1, 25-45. https://doi.org/10.1080/19463011003750657

Hwang, M. (1993). Factors affecting Japanese, Korean, and Taiwanese students' passiveness in oral interaction in English in the intermediate ESL spoken classroom (Unpublished doctoral dissertation). Available from Dissertation Abstract International database. (55-03, AAI9420164).

Jafari, S. M., \& Shokrpour, N. (2013). The role of L1 in ESP classrooms: A triangulated approach. International Journal of English and Education, 2(3), 90-104.

Jamshidi, A., \& Mahdieh, N. (2013). Learners' use of code switching in the English as a foreign language classroom. Australian Journal of Basic and Applied Sciences, 7(1), 186-190.

Jarvis, S. (2000). Methodological rigor in the study of transfer: Identifying L1 influence in the interlanguage lexicon. Language Learning, 50(2), 245-309. https://doi.org/10.1080/19463011003750657

Joe, Y., \& Lee, H. (2013). Does English-medium instruction benefit students in EFL contexts? A case study of medical students in Korea. Asia-Pacific Education Research, 22(2), 201-207. https://doi.org/10.1007/s40299-012-0003-7

Kafes, H. (2011). A neglected resource or an overvalued illusion: L1 use in the foreign language classroom. International Journal on New Trends in Education and Their Implications, 2(2), 128-140.

Kavaliauskienë, G., \& Kaminskienë, L. (2007). Translation as a learning tool in English for specific purposes. KALBOTYRA, 57(3), 132-139.

Khresheh, A. (2012). Exploring when and why to use Arabic in the Saudi Arabian EFL classroom: Viewing L1 use as eclectic technique. English Language Teaching, 5(6), 78-88. https://doi.org/10.5539/elt.v5n6p78

Kovacic, A., \& Kirinic, V. (2011). To Use or Not to Use: First Language in Tertiary Instruction of English as a Foreign Language. 1st International Conference on Foreign Language Teaching and Applied Linguistics, Sarajevo.

Krashen, S. (1982). Principles and Practice in Second Language Acquisition. Oxford: Pergamon.

Lasagabaster, D. (2013). The use of the L1 in CLIL classes: The teachers' perspective. Latin American Journal of Content and Language Integrated Learning, 6(2), 1-21. https://doi.org/10.5294/lacli1.2013.6.2.1

Levine, G. (2003). Target language use, first language use, and anxiety: Report of a questionnaire study. Modern Language Journal, 87, 343-364. https://doi.org/10.1111/1540-4781.00194

Lightbown, P. M., \& Spada, N. (2013). How Languages Are Learned (4th ed.) Oxford: Oxford University Press.

Lindsay, C., \& Knight, P. (2006). Learning and teaching English: A course for teachers. Oxford: Oxford University Press

Macaro, E. (2001). Analysing student teachers' codeswitching in foreign language classrooms: Theories and decision making. The Modern Language Journal, 85(4), 531-548. https://doi.org/10.1111/0026-7902.00124

Mart, Ç. T. (2013).The facilitating role of L1 in ESL classes. International Journal of Academic Research in Business and Social Sciences, 3(1), 9-14.

McMillan, B. A., \& Rivers, D. J. (2011). The practice of policy: Teacher attitudes toward "English only". System, 39, 251-263. https://doi.org/10.1016/j.system.2011.04.011

Meyer, H. (2008). The pedagogical implications of L1 use in the L2 classroom. Maebashi Kyodai Gakuen College Ronsyu, 8, 147-159.

Miles, R. (2004). Evaluating the use of L1 in the English lan-guage classroom (Master's thesis). University of Birmingham, United Kingdom.

Nation, P. (2003). The role of the first language in foreign language learning. Asian EFL Journal, 5(2).

Nazary, M. (2008). The Role of L1 in L2 Acquisition: Attitudes of Iranian University Students. Novitas Royal, 2(2), 138-153.

Norman, J. (2008). Benefits and drawbacks to L1 use in the L2 classroom. In K. Bradford Watts, T. Muller, \& M. Swanson (Eds.), JALT2007 Conference Proceedings. Challenging Assumptions: Looking In, Looking Out 
(pp. 691-701). Tokyo: JALT

Park, C. (1998). Why not speak English? A study of language use among Korean students in an intensive English program in the United States (Doctoral dissertation). Available from Digital Dissertations database. (UMI No. 9833631).

Polio, C., \& Duff, P. (1994). Teachers' language use in university foreign language classrooms: A qualitative analysis of English and target language alternation. The Modern Language Journal, 78, 313-326. https://doi.org/10.1111/j.1540-4781.1994.tb02045.x

Rayati, R. A., Yaqubi, B., \& Harsejsani, R. (2012). L1 use and Language-Related Episodes (LREs) in an EFL setting. The Journal of Teaching Language Skills (JTLS), 3(4), 99-125.

Rawan, H. H. (2016). Developing Learner Autonomy in Vocabulary Learning in classroom: How and Why can it be Fostered? Procedia - Social and Behavioral Sciences, 232, 784-791. https://doi.org/10.1016/j.sbspro.2016.10.106

Rivers, D. J. (2011). Strategies and struggles in the ELT classroom: language policy, learner autonomy and innovative practice. Language Awareness, 20, 31-43. https://doi.org/10.1080/09658416.2010.537343

Rolin-Ianziti, J., \& Varshney, R. (2008). Students' views regarding the use of the first language: an exploratory study in a tertiary context maximizing target language use. The Canadian Modern Language Review, 65(2) 249-273. https://doi.org/10.3138/cmlr.65.2.249

Rolin-Ianziti, J., \& Brownlie, S. (2002). Teacher use of learners' native language in the foreign language classroom. The Canadian Modern Language Review, 58, 402-426. https://doi.org/10.3138/cmlr.58.3.402

Savignon, S. (1987). Communicative language teaching. Theory into Practice, 26, 235-242. https://doi.org/10.1080/00405848709543281

Schweers, C.W. (1999). Using L1 in the L2 classroom. English Teaching Forum, 37(2).

Sharma, K. (2006). Mother tongue use in English classroom. Journal of NELTA, 11(1-2), 80-87.

Sipra, M. A. (2007). Bilingualism as teaching aid in a language class: L1 as a facilitator in teaching/ learning process of L2 at intermediate/certificate level. Unpublished Doctoral Dissertation, National University of Modern Languages, Islamabad.

Spada, N., \& Lightbown, P. (1999). Instruction, first language influence, and developmental readiness in second language acquisition. Modern Language Journal, 83, 1-22. https://doi.org/10.1111/0026-7902.00002

Spahiu, I. (2013).Using native language in ESL classroom. IJ-ELTS: International Journal of English Language \& Translation Studies, 1(2), 243-248.

Spivey, N. (1997). The constructivist metaphor: Reading, writing, and the making of meaning. London: Academic Press.

Storch, N., \& Wigglesworth, G. (2003). Is there a role for the use of the L1 in an L2 setting? TESOL Quarterly, 37(4), 760-770. https://doi.org/10.2307/3588224

Swain, M., \& Lapkin, S. (2000). Task-based second language learning: the uses of the first language. Language Teaching Research, 4(3), 251- 274. https://doi.org/10.1191/136216800125087

Tomizawa, S. (1990). Psychological and sociocultural factors affecting the Japanese adult ESL learners' inactiveness in oral interaction in English (Doctoral dissertation). Available from Dissertation Abstracts International database. (51-08, AAI9033743).

Tumbull, M. (1999). Multidimensional project-based teaching in French second language (FSL): A process-product case study. The Modern Language Journal, 83, 548-568. https://doi.org/10.1111/0026-7902.00040

Turnbull, M. (2001). There is a role for the L1 in second and foreign language teaching, but... The Canadian Modern Language Review, 57, 531-540. https://doi.org/10.3138/cmlr.57.4.531

Turnbull, M., \& Dailey-O'Cain, J. (2009). First language use in second and foreign language learning. Bristol, UK: Multilingual Matters.

Wells, G. (1999). Using L1 to master L2: A response to Anton and DiCamilla's "Social-cognitive functions of L1 collaborative interaction in the L2 classroom." Modern Language Journal, 83, 248-254. https://doi.org/10.1111/0026-7902.00019 
Wen, J. P. Elizabeth, M. N., Sally, T., Xiang, R. W., Chong, Z., Jian, Z. L., \& Hui, S. T. (2014). Emerging perceptions of teacher quality and teacher development in China. International Journal of Educational Development, 34, 77-89. https://doi.org/10.1016/j.ijedudev.2013.04.005

Yamamoto-Wilson, J. (1997). Can a knowledge of Japanese help our EFL teaching? The Language Teacher, $21(1), 69$.

\section{Copyrights}

Copyright for this article is retained by the author(s), with first publication rights granted to the journal.

This is an open-access article distributed under the terms and conditions of the Creative Commons Attribution license (http://creativecommons.org/licenses/by/4.0/). 